\title{
Biopsychosocial Determinants of Visual Inspection Acetic-Acid Test Uptake in Sragen, Central Java
}

\author{
Dewi Saptowati1), Ambar Mudigdo²), Bhisma Murti1) \\ 1)Masters Program in Public Health, Universitas Sebelas Maret \\ 2)Faculty of Medicine, Universitas Sebelas Maret
}

\begin{abstract}
Background: Cervical cancer ranks second among the top ten leading causes of death in women in the world, especially in developing countries. Cervical cancer can be cured if detected early. A simple and common method in early detection of cervical cancer is a visual inspection acetatic-acid (VIA) test. This study aimed to analyze the biopsychosocial factors associated with use of VIA test, using health belief model and a path analysis model.

Subjects and Method: This was an analytic observational study with a cross-sectional design. The study was carried out in Sragen, Central Java, from October 2017 to May 2018. A sample of 200 women was selected by fixed disease sampling. The dependent variable was utilization of VIA test. The dependent variables were intention, self-efficacy, perceived benefit, perceived barrier, attitude, subjective norm, knowledge, education, perceived susceptibility, perceived seriousness, and number of children. Data on VIA test were obtained from medical record. The other variables were measured by questionnaire and analyzed by path analysis.

Results: Use of VIA test was directly and positively affected by intention $(b=3.50$; 95\% CI= 1.20 to $5.79 ; p=0.003)$, perceived benefit $(b=5.21 ; 95 \% \mathrm{CI}=1.98$ to $8.44 ; \mathrm{p}=0.002)$, and number of children ( $b=4.23 ; 95 \% \mathrm{CI}=1.61$ to $6.86 ; \mathrm{p}<0.001)$. Use of VIA test was directly and negatively affected by perceived barrier $(b=-5.98 ; 95 \% \mathrm{CI}=-8.83$ to $-3.13 ; \mathrm{p}<0.001)$. Use of VIA test was indirectly affected by attitude, subjective norm, self-efficacy, knowledge, education, perceived susceptibility, and perceived seriousness.
\end{abstract}

Conclusion: Use of VIA test is directly and positively affected by intention, perceived benefit, and number of children, but negatively affected by perceived barrier.

Keywords: visual inspection acetic-acid test, determinants, biopsychosocial, health belief model

\section{Correspondence:}

Dewi Saptowati. Masters Program in Public Health, Universitas Sebelas Maret, Jl. Ir. Sutami No. 36 A, Surakarta 57126, Central Java. Email: dewi.saptowati@gmail.com.

\section{BACKGROUND}

One of the most common cancers in women is cervical cancer. It ranks second among the top ten leading causes of death in women all over the world, especially in developing countries. Cervical cancer caused 275,000 deaths per year and more than $85 \%$ were diagnosed in women with low economical conditions (Ndejjo et al., 2017; Wiebe et al., 2012).
Based on data from the Central Bureau of Statistics, the number of female population in Indonesia in 2016 was $128,716,296$ (49.75\%). While the number of women of reproductive age of 20-49 years were $58,913,907$ people (45.77\%). Women of reproductive age are at risk of cervical cancer if the reproductive health is not maintained properly. According to data Riskesdas 2013, the number of cervical cancer patients in Indonesia was 98,692 
women. Cervical cancer patients are most reported in East Java, Central Java, and West Java in Central Java Province the number of cervical cancer patients is 19,734 cases. In Sragen regency, the number of cases of cervical cancer reached 216 cases in 2016 (Ministry of Health, 2015, 2017; Health Department of Sragen Regency, 2016).

Cervical cancer can be cured if it is detected at an early stage, but more than $70 \%$ of patients check their condition at an advanced stage, so patients are late to receive treatment therapy and increase the risk of death (Mahanta et al., 2012).

Considering the increase of death number from cervical cancer each year, the Indonesian Ministry of Health issued a policy related to the early detection program of cervical cancer. One of the most widely used methods of early detection of cervical cancer is the Visual Inspection Acetic Acid test (VIA). VIA method is more widely used than other methods because it has several advantages, including: the process of examination more quickly, easily, and has a fairly high level of accuracy (WHO, 2012; Ministry of Health, 2015). Based on data of Cancer Sub Directorate Directorate of Non Communicable Disease Control (PPTM) Ministry of Health RI from year 2007 until 2014, the coverage of early detection program of cervical cancer was up to 904,099 people $(2.45 \%)$ with positive VIA result of 44,654 people (4.94\%) and cancer suspect cervix of 1,056 people (1.2 per 1,00o people). The latest data indicate that the coverage of VIA method examination and clinical breast examination (SADANIS) in Indonesia from 2008-2016 was $1,623,913$ people (4.34\%). The coverage is still very far from the total target of 37.5 million Indonesian women (Kemenkes, 2016). In 2015, the number of women of childbearing age in Central Java Province who have early detection of cervical cancer and breast cancer was 18,954 people (0.30\%), with positive VIA result of 1,868 people (9.86\%). The scope of detection early detection is also still far from the set target of $10 \%$ (Central Java Provincial Health Office, 2015). While in Sragen regency, in 2016 there were 437 women aged $30-50$ years $(0.33 \%)$ who perform early detection of cervical cancer and breast cancer from a total of 130,560 women. From the screening, the results of positive VIA result were 31 people (Sragen Health Office, 2016).

The low participation of women of childbearing age in early detection of cervical cancer using VIA method may be caused by various factors. Some studies mention individual factors and environmental factors greatly affect women's behavior to perform early detection of cervical cancer using VIA method. This is in accordance with the biopsychosocial model of health, in which biological, psychological, and social aspects contribute greatly to one's health status (Sidabutar et al., 2017; Nwobodo, 2015; Murti, 2016a). When it comes to theory, factors that influence a person's healthy lifestyle can be analyzed using behavior change models such as the Health Belief Model (HBM), Theory of Planned Behavior (TPB), and the PRECEDE-PROCEED model. The purpose of this study was to analyze the biopsychosocial factors of the use of visual inspection test of acetate acetate in Sragen regency, Central Java, Indonesia, using path analysis.

\footnotetext{
SUBJECTS AND METHOD

\section{Study Design}

This was an analytic observational study with a cross sectional design. The study was conducted in Sragen, Central Java, Indonesia, from October 2017 to May 2018.
} 


\section{Population and samples}

The source population in this study were women of reproductive age in Sragen, Central Java. A sample of 200 women was selected by fixed disease sampling.

\section{Study variables}

The dependent variable was the use of VIA test. The independent variables were intention, self efficacy, perceived benefit, perceived barrier, attitude, subjective norm, knowledge, education, perceived susceptibility, perceived seriousness, and number of children.

\section{Operational definition of variables}

VIA test was defined as a method of early detection of cervical cancer by applying acetic acid $3 \%-5 \%$ in the cervix among women reproductive age. The measurement scale was categorical.

Perceived susceptibility was defined as a positive or negative assessment of the risk for suffering from cervical cancer. The data were collected by questionnaire. The measurement scale was continuous.

Percived seriousness was defined as an individual's subjective perception of how severe the physical and social consequences of cervical cancer. The data were collected by questionnaire. The measurement scale was continuous.

Perceived benefit was defined as the confidence that individuals perceive to the benefits of VIA testing as an early detection of cervical cancer. The data were collected by questionnaire. The measurement scale was continuous.

Perceived barrier was defined as a belief about an individual's constraints or barriers to an VIA test. The data were collected by questionnaire. The measurement scale was continuous.

Self efficacy was defined as individual belief/ability to perform early detection of cervical cancer with VIA test. The data were collected by questionnaire. The measurement scale was continuous.

Intention was defined as the desire of the mother to do or not to do the VIA test. The data were collected by questionnaire. The measurement scale was continuous.

Attitude was defined as women response in the form of a positive or negative assessment related to the ease or obstacles to affect the mother in performing the VIA test. The data were collected by questionnaire. The measurement scale was continuous.

Subjective norm was defined as women belief in the perceived support from the society, family, and peer environments that have an influence on women decisions for VIA testing. The data were collected by questionnaire. The measurement scale was continuous.

Maternal education was defined as the process of changing attitudes or behaviors through the teaching and training effort that the mother has done. The data were collected by questionnaire. The measurement scale was categorical.

Maternal knowledge was defined as the information the mother knows about cervical cancer and VIA tests. The data were collected by questionnaire. The measurement scale was continuous.

Number of children was defined as the number of children born by the mother. The data were collected by questionnaire. The measurement scale was continuous.

\section{Data Analysis}

Univariate analysis was conducted to see the frequency distribution and percentage characteristics of the subjects. Bivariate analysis was conducted to study the relationship between use of VIA test and the independent variable using chi-square test and odds ratio (OR) with 95\% confidence level (CI). Furthermore, multivariate analysis employed path analysis. 
Journal of Maternal and Child Health (2018), 3(3): 197-206

https://doi.org/10.26911/thejmch.2018.03.03.04

\section{Research Ethics}

The research ethics included informed consent, anonymity, confidentiality and ethical clearance. The ethical clearance was obtained from the Research Ethics Committee, Dr. Moewardi hospital, Surakarta, Central Java, Indonesia.

Table 1. Sample Characteristics

\begin{tabular}{|c|c|c|c|c|c|c|c|}
\hline \multirow{2}{*}{ Variable } & \multicolumn{2}{|c|}{ No VIA Test } & \multicolumn{2}{|c|}{ VIA Test } & \multirow[t]{2}{*}{ OR } & \multirow[t]{2}{*}{$95 \% \mathrm{CI}$} & \multirow[t]{2}{*}{$\mathbf{p}$} \\
\hline & $n=150$ & $\%$ & $\mathbf{n}=\mathbf{5 0}$ & $\%$ & & & \\
\hline Education & & & & & & 2.32 to & \\
\hline$<$ Senior high school & 50 & 94.3 & 3 & 5.7 & 7.83 & 26.41 & $<0.001$ \\
\hline$\geq$ Senior high school & 100 & 68 & 47 & 32 & & & \\
\hline Knowledge & & & & & & 4.54 to & $<0.001$ \\
\hline Low & 67 & 97.16 & 2 & 2.9 & 19.37 & 82.64 & \\
\hline High & 83 & 3.4 & 48 & 36.6 & & & \\
\hline Number of Children & & & & & & 3.02 to & $<0.001$ \\
\hline$\leq 2$ & 85 & 91.4 & 8 & 8.6 & 6.86 & 15.62 & \\
\hline$>2$ & 65 & 60.7 & 42 & 39.3 & & & \\
\hline Perceived & & & & & & 1.4 to & \\
\hline susceptibility & 66 & 100 & o & o & 1.59 & 1.82 & $<0.001$ \\
\hline Weak & 84 & 62.7 & 50 & $37 \cdot 3$ & & & \\
\hline Strong & & & & & & & \\
\hline Perceived seriousness & & & & & & 3.94 to & \\
\hline Weak & 75 & 94.9 & 4 & 5.1 & 11.5 & 33.55 & $<0.001$ \\
\hline Strong & 75 & 62 & 46 & 38 & & & \\
\hline Subjective norm & & & & & & 16.87 to & $<0.001$ \\
\hline Weak & 118 & $97 \cdot 5$ & 3 & 2.5 & 57.77 & 197.8 & \\
\hline Strong & 32 & 40.5 & 47 & 59.5 & & & \\
\hline Attitude & & & & & & 21.45 to & $<0.001$ \\
\hline Negative & 115 & 99.1 & 1 & 0.9 & 161 & 1208.45 & \\
\hline Positive & 35 & 41.7 & 49 & 58.3 & & & \\
\hline Intention & & & & & & 1.80 to & \\
\hline Weak & 111 & 100 & $\mathrm{O}$ & o & 2.28 & 2.89 & $<0.001$ \\
\hline Strong & 39 & 43.8 & 50 & 56.2 & & & \\
\hline Self-Efficacy & & & & & & 1.68 to & \\
\hline Low & 103 & 100 & $\mathrm{O}$ & $\mathrm{O}$ & 2.06 & 2.53 & $<0.001$ \\
\hline High & 47 & 48.5 & 50 & 51.5 & & & \\
\hline Perceived benefit & & & & & & 13.55 to & \\
\hline Low & 101 & 99 & 1 & 1 & 101 & 753.08 & $<0.001$ \\
\hline High & 49 & 50 & 49 & 50 & & & \\
\hline Perceived barrier & & & & & & $<0.01$ to & \\
\hline Low & 24 & 33.3 & 48 & 66.7 & 0.01 & 0.04 & $<0.001$ \\
\hline High & 126 & 98.4 & 2 & 1.6 & & & \\
\hline
\end{tabular}

Bivariate analyses and the respective odds ratios (Table 1) showed that the VIA uptake increased with higher education attainment, better knowledge, higher parity,

\section{RESULTS}

\section{Sample characteristics}

As many as 200 women of reproductive age consisting of 50 women with VIA test and 150 women without VIA test, were selected for this study.

\section{Education}

$\geq$ Senior high school

Knowledge

High

$\leq 2$

\section{Perceived}

Weak

Perceived seriousness

Subjective norm

Weak

Negative

Positive

Weak

Strong

Low

High

Low

Low

\section{No VIA} $=150$ 
higher self efficacy, higher perceived benefit, and lower perceived barrier.

\section{Multivariate analysis by using path analysis}

Figure 1 depicted structural model of path analysis with parameter estimates. Roughly speaking the resulting path diagram supported the Theory of Planned Behavior where VIA uptake was preceded by intention. Likewise, it also supported Health Belief Model in that perceived susceptibility, severity, benefit, barier, and self efficacy, predicted VIA uptake.

Table 2 showed the results of path analysis that the use of VIA was directly and positively associated with intention $(\mathrm{b}=$ $3.50 ; 95 \% \mathrm{CI}=1.20$ to $5.79 ; \mathrm{p}=0.003$ ), perceived benefit $(b=5.21 ; 95 \% \mathrm{CI}=1.98$ to 8.44; $\mathrm{p}=0.002$ ), and number of children $(b=4.23 ; 95 \% \mathrm{CI}=1.61$ to $6.86 ; \mathrm{p}<0.001)$. Use of VIA directly and negatively associated with perceived barrier $(b=-5.98$; $95 \% \mathrm{CI}=-8.83$ to $-3.13 ; \mathrm{p}<0.001)$.
Intention was affected by attitude $(\mathrm{b}=$ 2.04; $95 \% \mathrm{CI}=0.64$ to $3.45 ; \mathrm{p}=0.004)$, subjective norm $(b=3.06 ; 95 \% \mathrm{CI}=0.89$ to 5.22; $\mathrm{p}=0.006)$, and self-efficacy $(\mathrm{b}=2.47$; 95\% $\mathrm{CI}=1.59$ to $3.34 ; \mathrm{p}<0.001)$.

Perceived benefit was affected by perceived barrier $(b=-2.14 ; 95 \% \mathrm{CI}=-2.87$ to $-1.41 ; \mathrm{p}<0.001)$ and knowledge $(\mathrm{b}=0.77$; 95\% CI= 0.07 to $1.47 ; \mathrm{p}=0.031$ ).

Perceived barrier was affected by knowledge $(\mathrm{b}=1.67 ; 95 \% \mathrm{CI}=-2.42$ to -0.91 ; $\mathrm{p}<0.001)$. Knowledge was affected by education $(b=0.63 ; 95 \% \mathrm{CI}=-0.01$ to $1.27 ; \mathrm{p}=$ o.056). Perceived susceptibility was affected by education $(b=0.93 ; 95 \% \mathrm{CI}=0.27$ to 1.59; $\mathrm{p}=0.006)$. Perceived seriousness was affected by education $(b=0.92 ; 95 \% \mathrm{CI}=$ 0.24 to $1.59 ; \mathrm{p}=0.008)$. Attitude was affected by perceived susceptibility $(b=1.19 ; 95 \%$ $\mathrm{CI}=-0.11$ to $2.50 ; \mathrm{p}=0.072)$ and perceived seriousness $(\mathrm{b}=1.17$; $95 \% \mathrm{CI}=-0.19$ to 2.55 ; $\mathrm{p}=0.093)$.

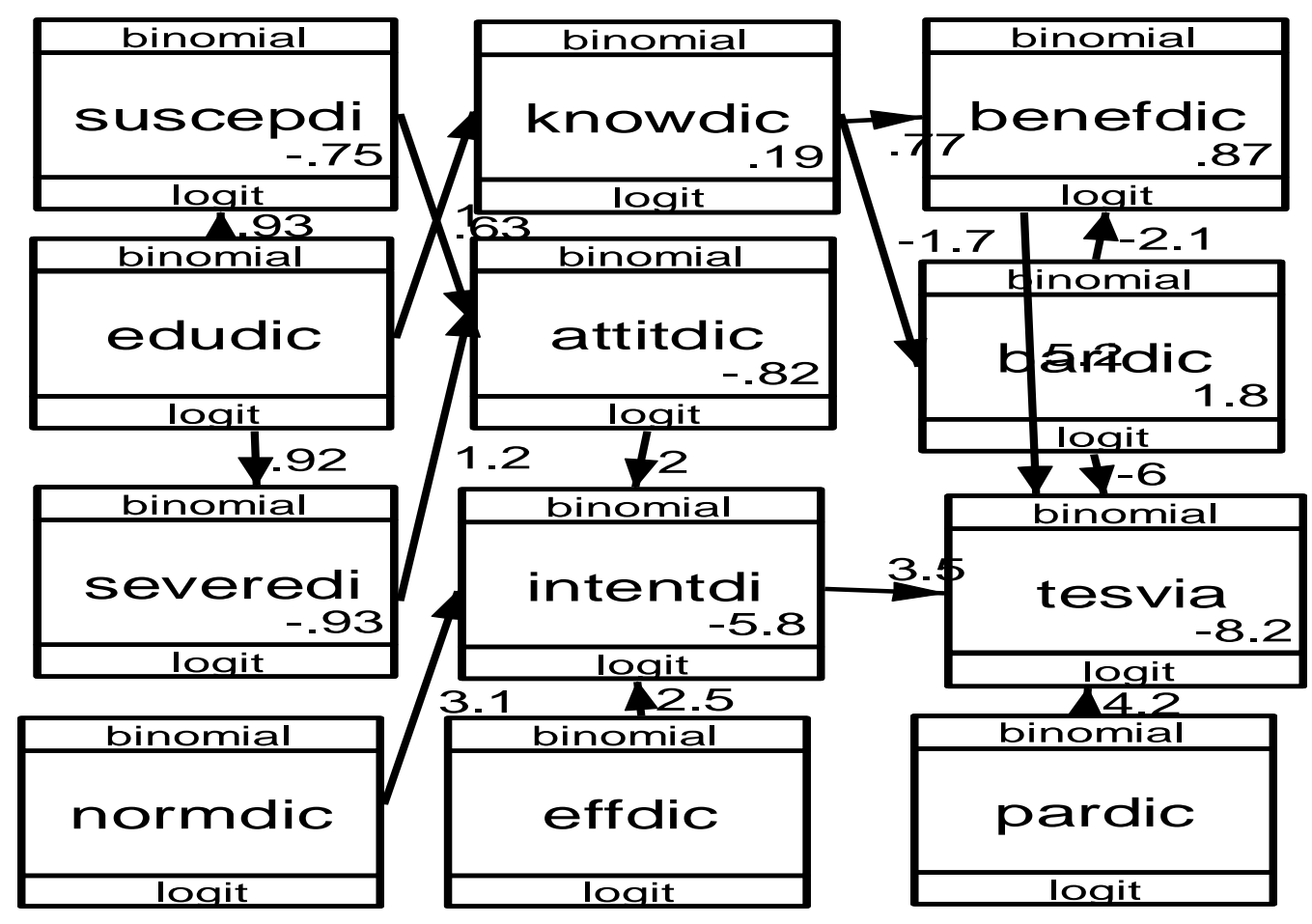

Figure 1. Structural model with estimation 
Journal of Maternal and Child Health (2018), 3(3): 197-206

https://doi.org/10.26911/thejmch.2018.03.03.04

Table 2. The result of path analysis

\begin{tabular}{|c|c|c|c|c|c|c|}
\hline \multirow[b]{2}{*}{ Dependent Variable } & & \multirow{2}{*}{$\begin{array}{c}\text { Independent } \\
\text { variable }\end{array}$} & \multirow[b]{2}{*}{ b } & \multicolumn{2}{|c|}{$95 \% \mathrm{CI}$} & \multirow[b]{2}{*}{$\mathbf{p}$} \\
\hline & & & & $\begin{array}{c}\text { Lower } \\
\text { Limit }\end{array}$ & $\begin{array}{l}\text { Upper } \\
\text { Limit }\end{array}$ & \\
\hline \multicolumn{7}{|l|}{ Direct Effect } \\
\hline VIA test & $\leftarrow$ & Intention & 3.50 & 1.20 & 5.79 & 0.003 \\
\hline VIA test & $\leftarrow$ & Perceived barrier & -5.98 & -8.83 & -3.13 & $<0.001$ \\
\hline VIA test & $\leftarrow$ & Perceived benefit & 5.21 & 1.98 & 8.44 & 0.002 \\
\hline VIA test & $\leftarrow$ & Number of children & 4.23 & 1.61 & 6.86 & $<0.001$ \\
\hline \multicolumn{7}{|l|}{ Indirect Effect } \\
\hline Intention & $\leftarrow$ & Attitude & 2.04 & 0.64 & 3.45 & 0.004 \\
\hline Intention & $\leftarrow$ & Subjective Norm & 3.06 & 0.89 & 5.22 & 0.006 \\
\hline Intention & $\leftarrow$ & Self-Efficacy & 2.47 & 1.59 & 3.34 & $<0.001$ \\
\hline Perceived Benefit & $\leftarrow$ & Perceived Barrier & -2.14 & -2.87 & -1.41 & $<0.001$ \\
\hline Perceived Benefit & $\leftarrow$ & Knowledge & 0.77 & 0.07 & 1.47 & 0.031 \\
\hline Perceived Barrier & $\leftarrow$ & Knowledge & 1.67 & -2.42 & -0.91 & $<0.001$ \\
\hline Knowledge & $\leftarrow$ & Education & 0.63 & -0.01 & 1.27 & 0.056 \\
\hline Perceived Susceptibility & $\leftarrow$ & Education & 0.93 & 0.27 & 1.59 & 0.006 \\
\hline Perceived Seriousness & $\leftarrow$ & Education & 0.92 & 0.24 & 1.59 & 0.008 \\
\hline Attitude & $\leftarrow$ & $\begin{array}{l}\text { Perceived } \\
\text { Susceptibility }\end{array}$ & 1.19 & -0.11 & 2.50 & 0.072 \\
\hline Attitude & $\leftarrow$ & $\begin{array}{l}\text { Perceived } \\
\text { Seriousness }\end{array}$ & 1.17 & -0.19 & 2.55 & 0.093 \\
\hline
\end{tabular}

\section{DISCUSSION \\ 1. The effect of intention on VIA test uptake}

The result of analysis showed that intention has an effect on the use of VIA test. Women with strong intention were 3.50 times more likely to conduct VIA test than women with weak intention. The result of this study was in line with a study by Anggraeni et al. (2016), which stated that the intention could affecte arly detection of cervical cancer on women in reproductive age.

\section{The effect of perceived benefit on VIA test uptake}

The result of analysis showed that perceived benefit has an effect on the use of VIA test. Women with high perceived benefit were 5.21 times more likely to conduct VIA test compared to women with low perceived benefit. The result of this study was in line with a study by Wakhidah et al. (2016), which stated that perceived benefit could affect early detection of cervical cancer on women in reproductive age.

\section{The effect of perceived barrier on VIA test uptake}

The result of analysis showed that perceived barrier has an effect on the use of VIA test. Women with high perceived barrier were 5.98 times less likely to conduct VIA test compared to women with low perceived barrier. The result of this study was in line with Wakhidah et al. (2016), which stated that perceived barrier could affect early detection of cervical cancer on women in reproductive age.

\section{The effect of the number of children on VIA test uptake}

The result of analysis showed that the number of children has an effect on the use of VIA test. Women who had larger number of children were 4.23 times more likely to conduct VIA test. The result of this study was in line with a study by Ncube et al. (2015), which stated that the number of 
children affected the decision to early detection of cervical cancer.

\section{The effect of self-efficacy on VIA test uptake}

The result of analysis showed that selfefficacy has an indirect effect on the use of VIA test. Women with high self-efficacy were 2.47 times less likely to conduct VIA test compared to women with low selfefficacy. The result of this study was in line with a study by Wakhidah et al. (2017), which reported that there was a relationship between self-efficacy and early detection of cervical cancer.

\section{The effect of attitude on VIA test uptake}

The result of analysis showed that attitude has an indirect effect on the use of VIA test. Women with positive attitude were 2.04 times more likely to conduct VIA test compared to womrn with negative attitude. The result of this study was in line with a study by Idowu et al. (2016), which reported that there was a relationship between attitude and early detection of cervical cancer.

\section{The effect of knowledge on VIA test uptake}

The result of analysis showed that knowledge has an indirect effect on the use of VIA test. The result of this study was is consistent with a study by Nurhasanah and Afiyanti (2017), which stated that knowledge was affected early detection of cervical cancer on women in reproductive age.

\section{The effect of education on VIA test uptake}

The result of analysis showed that education has an indirect effect on the use of VIA test. The result of this study was in line with a study by Wardhani et al. (2017) which stated that education was one of the factors affecting early detection of cervical cancer on women in reproductive age.

\section{The effect of subjective norm on VIA test uptake}

The result of analysis showed that subjective norm has an indirect effect on the use of VIA test. Women with strong subjective norms were 3.06 times more likely to conduct VIA test than mothers with weak subjective norms.

The result of this study was in line with a study by Anggraeni et al. (2016), which stated that there was a relationship between subjective norms and early detection of cervical cancer.

10. The effect of perceived susceptibility on VIA test uptake

The result of analysis showed that perceived susceptibility has an indirect effect on the use of VIA test. Women with strong perceived susceptibility were 1.19 times more likely to conduct VIA test than women with weak perceived susceptibility. The result of this study was in line with a study by Wakhidah et al. (2016), which stated that there was a relationship between perceived susceptibility and early detection of cervical cancer on women in reproductive age.

11. The effect of perceived seriousness on VIA test uptake

The result of analysis showed that perceived seriousness has an indirect effect on the use of VIA test. Women with positive perceived seriousness were 1.17 times more likely to conduct VIA test than women with negative perceived seriousness. The result of this study was in line with a study by Wakhidah et al. (2016), which reported that there was a relationship between perceived seriousness and early detection of cervical cancer on women in reproductive age.

\section{CONFLICT OF INTEREST}

None declared. 


\section{REFERENCES}

Ali CI, Makata NE, Ezenduka PO (2016). Cervical cancer: A health limiting condition. Gynecol Obstet. 6:378.

Anggraeni FD, Murti B, Dharmawan R. (2016). Path analysis and theory of planned behavior on using PAP smear as early detection of cervical cancer in Sewon I community health center, Bantul, Yogyakarta, Indonesia. Journal of Health Promotion and Behavior, 1(1):1-8 doi: 10.26911/thejhpb.2016.01.01.01.

American Center Society (2016). About cervical cancer. Available at: https://www.cancer.org/cancer/cervical-cancer/about/what-is-cervical-cancer.html.

Azwar S (2013). Sikap manusia teori dan pengukurannya. Edisi 2. Yogyakarta: Pustaka Pelajar.

Bayu H, Berhe Y, Mulat A, Alemu A (2016). Cervical cancer screening service uptake and associated factors among age eligible women in Mekelle Zone, Northern Ethiopia, 2015: A community based study using health belief model. PLoS ONE. 11(3): e0149908.

Bermudez A, Bhatla N, Leung E (2015). Cancer of cervix uteri. International Journal of Gynecology and Obstetrics. 131: S88-S95.

Binkley CJ, Johnson KW (2014). Application of the PRECEDE-PROCEED planning model in designing an oral health strategy. J Theory Pract Dent Public Health. 1(3): 2-18.

Burke E (2013). The health belief model.

Crosbie EJ, Einstein MH, Franceschi S, Kitchener HC (2013). Human papillomavirus and cervical cancer. The Lancet. 382: 889-99.

Dinas Kesehatan Provinsi Jawa Tengah. (2015). Profil kesehatan provinsi Jawa Tengah tahun 2015.
Dinas Kesehatan Kabupaten Sragen (2016). Profil kesehatan tahun 2016.

Emdadi S, Hazavehie SM, Soltanian A, Bashirian S, HeidariMoghadam R (2015). Predictive factors of regular physical activity among middle-aged women in the West of Iran, Hamadan: Application of PRECEDE Model. Journal of Research in Health Sciences. 15(4): 244-9.

Epton T, Norman P, Harris P, Webb T, Snowsill FA, Sheeran P (2014). Development of theory-based health messages: three-phase programme of formative research. Health Promotion International.30(3).

Ersin F, Zuhal B (2011). Effect of health belief model and health promotion model on breast cancer early diagnosis behavior: A systematic review. Asian Pacific Journal of Cancer Prevention. 12: 2555-2562.

Hohman ZP, Crano WD, Siegel JT, Alvaro EM (2014). Attitude ambivalence, friend norms, and adolescent drug use. Prev Sci. 15(1): 65-74.

Idowu A, Olowookere SA, Fagbemi AT, Ogunlaja OA (2016). Determinants of cervical cancer screening uptake among women in Ilorin, North Central Nigeria: A community-based study. Journal of Cancer Epidemiology. doi: 10.1155/2016/6469240.

Kementerian Kesehatan RI (2015). Situasi penyakit kanker. Jakarta: Pusat Data dan Informasi Kementerian Kesehatan Republik Indonesia.

(2016). Oktober 2016 bulan peduli kanker payudara. Jakarta: Pusat Data danInformasi Kementerian Kesehatan Republik Indonesia.

(2017). Data dan informasi profil kesehatan Indonesia 2016. Jakarta: Pusat Data dan Informasi Kementerian Kesehatan Republik Indonesia. 
Kessler TA (2017). Cervical cancer: prevention and early detection. Seminar in Oncology Nursing. 33(2):172-183.

Komite Penanggulangan Kanker Nasional. (2014). Panduan penatalaksanaan kanker serviks. Jakarta: Kementerian Kesehatan Republik Indonesia.

Lyimo FS, Beran TN (2012). Demographic, knowledge, attitudinal, and accessibility factors associated with uptake of cervical cancer screening among women in A Rural District of Tanzania: Three public policy implications. BMC Public Health. 12: 22.

Mahanta DC, Nath NR. (2012) 'On the Study of risk factors of ca. cervix and ca. breast: a case study in Assam. Bonfring International Journal of Data Mining, 2(2).

Murti B (2013). Desain dan ukuran sampel untuk penelitian kuantitatif dan kualitatif di bidang kesehatan. Yogyakarta: GadjahMada University Press.

(2016a). Prinsip dan metode riset epidemiologi. Surakarta: Program Studi Ilmu Kesehatan Masyarakat, Program Pascasarjana, Universitas Sebelas Maret.

(2016b). How to conduct path analysis and structural equation model for health research. Surakarta: International Conference on Public Health. Available at: http://theicph.com/wp-content/uploads/2016/o9/How-to-conduct-Path-Analysis-andSEM-for-Health-Research_Prof.Bhisma-Murti.pdf

National Cancer Institute (2016). Human papillomavirus (HPV) vaccines. Available at: https://www.cancer.gov/about-cancer/causes-prevention/risk/infectious-agents/hpv-vaccine-factsheet.

Ncube B, Bey A, Knight J, Bessler P, Jolly PE (2015). Factors associated with the uptake of cervical cancer screening among women in Portland, Jamaica. North American Journal Medical Sciences. 7(3): 104-113. doi: 10.4103/1947-2714.153922.

Ndejjo R, Mukama T, Musinguzi G, Halage AA, Ssempebwa JC, Musoke D. (2017) Women's in intention to screen and willingness to vaccinate their daughters against cervical cancer - a cross sectional study in Eastern Uganda. BMC Public Health (2017) 17:255.

Nurbeti M, Jamil NA, Kuntari T, Sunarto, Ghazali HPL (2012). Ilmu kesehatan masyarakat untuk kompetensi dokter umum. Yogyakarta: Universitas Islam Indonesia.

Nurhasanah AY (2017). Factors affecting behaviors of cervical cancer screening using via (visual inspection with acetic acid) method on women in Srengseng Sawah Jakarta Indonesia. UI Proceedings on Health and Medicine.Vol.1.

Nwobodo H, Ba-Break M (2015). Analysis of the determinants of low cervical cancer screening uptake among Nigerian women. Journal of Public Health in Africa, 6: 484.

Rasjidi I (2009). Epidemiologi kanker serviks. Indonesian Journal of Cancer. 3(3): 103-108.

Rawlett K (2011). Analytical evaluation of the health belief model and the vulnerable populations conceptual model applied to a medically underserved, rural population. International Journal of Applied Science and Technology. 1(2): 15-21.

Saslow D, Philip E, Castle, Thomas C, Diane $\mathrm{D}$, et al. (2007). American cancer society guideline for human papillomavirus (HPV) Vaccine Use to Prevent Cervical Cancer and Its Precursors. CA Cancer J Clin. 57:7-28. 
Sawaya GF, Huchko MJ (2017). Cervical cancer screening. Medical Clinics of North America. 101(4): 743-753.

Sidabutar S, Martini S, Wahyuni CU (2017). Analysis of factors affecting women of childbearing age to screen using visual inspection with acetic acid. Osong Public Health Res Perspect. 8(1):61-64.

Tarkang E, Francis Z (2015). Application of the Health Belief Model (HBM) in HIV prevention: A literature review. Central African Journal of Public Health. 1 (1): 1-8.

Wakhidah MS, Hastuti URB, Dewi YLR (2017). The influence of personal factor, husband's support, health workers and peers toward the use of VIA screening among women of reproductive age in the regency of Karanganyar. Journal of Health Pro- motion and Behavior (2017), 2(2): 124-137. doi: 10.26911/thejhpb. 2017.02.02.03.

Wardhani GK, Mudigdo A, Qadrijati I (2017). Path analysis on the determinants of Pap smear utilization for cervical cancer early detection in women of reproductive age. Journal of Health Promotion and Behavior, 2(4): 359-370. doi: 10.26911/ thejhpb.2017.02.04.08.

Wiebe E, Denny L, Thomas G (2012). Cancer of the cervix uteri. International Journal of Gynecology and Obstetrics, 11952: S100-S109.

World Health Organization (2012) Prevention of cervical cancer through screening using visual inspection with acetic acid (VIA) and treatment with cryotherapy. Geneva, Switzerland: the WHO Document Production Services. 